\title{
STUDI PENDAHULUAN PENGIMPLEMENTASIAN KURIKULUM 2013 DALAM MENGINTEGRASIKAN PENDEKATAN SAINTIFIK MELALUI MODEL INKUIRI DAN AUTHENTIC ASSESSMENT DALAM PEMBELAJARAN IPA DI KOTA PADANG ${ }^{1}$
}

\author{
Prof. Dr. Festiyed, MS ${ }^{1)}$, Hp 08126742403 \\ 1) Dosen Fisika FMIPA Universitas Negeri Padang, Padang
}

\begin{abstract}
This study is a preliminary phase of research on the design of the device of learning by integrating scientific approaches, models inkuiri and authentic assessment in learning the IPA in Padang city which aims to study and compile data on actual, new and comprehensif using method of mix (simultaneous qualitative and quantitative). For qualitative data obtained through (1) interview to the principal or Deputy School curriculum areas Kepla, teacher observation, (2) pay attention to the environment of the school, curriculum documents and record local conditions, labor and library (light intensity and sound). Quantitative data instruments used multiple choice, multiple response, the scale Likert and semantic differential. From the results of research on curriculum as an idea: the formulation of the vision and mission have yet to accommodate the aspirations of all the citizens of the school, and not to involve them, as a result it is difficult to be obtained strong support from the citizens of the school in its implementation. The curriculum as the process and the curriculum implemented have been implemented but not related to the idea of curriculum as. So, although has been applied curriculum 2013 at the school in fact many schools still use old curriculum ( KTSP) . So that creativity, innovation of teachers and principals looked doubtful and reluctant to seek ways to implement new curriculum in 2013 that fit with regional conditions and characteristics of students. Suggested the socialization of Jakarta followed by all people associated with education ranging from producing college teachers, teacher candidates, department of education, LPMP and all the schools that would run the curriculum .
\end{abstract}

Keywords: idea , the process, and the implementation of the curriculum 2013

\footnotetext{
${ }^{1}$ Disajikan pada SEMIRATA, Universitas Tanjung Pura Pontianak 6-9 Mai 2015
} 


\section{PENDAHULUAN}

Berbagai upaya untuk meningkatkan mutu pendidikan telah dilakukan oleh pemerintah, salah satu diantaranya adalah penyempurnaan kurikulum yang disebut dengan Kurikulum 2013. Pemberlakuan Kurikulum 2013, telah ditetapkan dalam peraturan Menteri Pendidikan Nasional No. 160 tahun 2014. Pengembangan kurikulum pada dasarnya merupakan konsekuensi logis dari sifat dasar pendidikan yang dinamis, senantiasa bergerak mengikuti dan menyesuaikan dengan perubahan faktor-faktor yang melandasinya, baik filosofis, psikologis, sosiologis, IPTEK dan faktor-faktor lainnya. Kurikulum 2013 menekankan pada integrasi akademis dan karakter, penyederhanaan jumlah mata pelajaran, tematik-integratif.

Dalam rangka implementasi kurikulum 2013, usaha yang telah dilakukan pemerintah, diantaranya; (1) Pelaksanaan kurikulum di seluruh sekolah dan jenjang pendidikan dengan tahapan: Juli 2013 (Kelas I, IV, VII, dan X), Juli 2014 (Kelas I, II, IV, V, VII, VIII, X, dan XI tahun 2014), Juli 2015, seluruh kelas dan seluruh sekolah SD/MI, SMP/MTs, SMA/MA, SMK/MAK telah melaksanakan sepenuhnya; (2) Pelatihan Guru, Kepala Sekolah dan Pengawas, dimulai dari tahun 2013-2015; (3) Pengembangan buku, dari tahun 2013-2015; (4) Implementasi Kurikulum 2013 mensyaratkan penataan administrasi, manajemen, kepemimpinan dan budaya kerja guru yang baru; (5) Pendampingan dalam bentuk Monitoring dan Evaluasi untuk menemukan kesulitan dan masalah implementasi dan upaya penanggulangan dimulai Juli 2013-2016.

Namun di lapangan (survey di SMP Negeri Padang, tanggal15 Februari 2014) pelaksanaan pembelajaran IPA Kurikulum 2013 disikapi secara berbeda oleh pelaku pendidikan. Belum semua warga sekolah dapat memahami secara utuh esensi Kurikulum 2013; sekolah masih menghadapi kesulitan dalam proses pelaksanaan, dan penilaian karena gagal mengerahkan sumber daya pendidikan secara optimal. Dokumen Kurikulum 2013 belum mampu mensinergikan seluruh kegiatan pengembangan ke arah yang diharapkan. Selanjutnya Aljufri B (1998), menyatakan kurang sinerginya sumberdaya pendidikan seperti: sumber daya manusia, sarana dan prasarana, manajemen serta pembiayaan mungkin merupakan penyebab timbulnya sikap apriori dan penolakan secara psikologis terhadap perubahan.

Meskipun sudah ada upaya untuk memecahkan masalah tersebut, seperti: yang telah dilakukan MGMP dalam mengembangkan dan melaksanakan kurikulum, memanfaatkan hasil penelitian, tetapi belum menyangkut masalah secara keseluruhan, hanya secara parsial, sehingga masih terdapat beberapa kelemahan. Jika hal ini terus dibiarkan dan tidak ada upaya untuk mencari akar permasalahan dan perbaikannya, maka proses pembelajaran tidak akan berjalan menurut semestinya seperti tertuang 
dalam kurikulum. Hal inilah yang menyebabkan kegagalan upaya peningkatan kualitas proses dan hasil belajar.

Sehubungan dengan permasalahan yang disebutkan di atas, maka diperlukan upaya-upaya kongkrit untuk mengiringi suksesnya penyempurnaan kurikulum ini. Semangat perubahan Kurikulum 2013 mensyaratkan sekolah membangun paradigma baru. Sekolah berhak menilai keberhasilan pelaksanaannya; apakah standar kompetensi dan kompetensi inti sudah dicapai oleh peserta didiknya. Model penilaian autentik yang menekankan kepada proses dan hasil. Fokus penelitian ini diarahkan untuk mempelajari dan menghimpun data secara comprehensive, baru dan aktual tentang implementasi Kurikulum 2013 untuk pembelajaran IPA (Ilmu Pengetahuan Alam) di SMP (Sekolah Menengah Pertama) Negeri dan Swasta kota Padang.

Pembelajaran IPA di SMP pada kurikulum tahun 2013 terdapat beberapa perubahan diantara adalah konsep pembelajarannya dikembangkan sebagai mata pelajaran integrative scienceatau "IPATerpadu" bukan sebagai pendidikan disiplin ilmu. Konsep keterpaduan ini ditunjukkan dalam Kompetensi Inti ( KI) dan Kompetensi Dasar (KD) pembelajaran IPA yakni di dalam satu KD sudah memadukan konsep-konsep IPA dari bidang ilmu biologi, fisika, dan ilmu pengetahuan bumi dan antariksa (IPBA). Keberhasilan pelaksanaan pembelajaran IPA terpadu akan lebih optimal jika guru dalam merencanakan pembelajaran tersebut mempertimbangkan kondisi dan potensi peserta didik serta kemampuan sumberdaya pendukung lainnya. Kondisi dan potensi peserta didik tersebut meliputi: minat, bakat, kebutuhan, dan kemampuan peserta didik. Sedangkan, yang dimaksud dengan kemampuan sumberdaya pendukung meliputi: kemampuan guru, ketersediaan sarana dan prasarana pembelajaran, serta kepedulian stakeholders sekolah (Permendikbud No.103 tahun 2014)

Pembelajaran terpadu membutuhkan cara penilaian outentik yang menyeluruh (komprehensif), yaitu menetapkan keberhasilan belajar peserta didik dari beberapa bidang kajian terkait yang dipadukan (Permendikbud No.104 tahun 2014). Dalam kaitan ini, guru selain dituntut untuk menyediakan teknik dan prosedur pelaksanaan penilaian dan pengukuran yang komprehensif, juga dituntut untuk berkoordinasi dengan guru lain, bila materi pelajaran berasal dari guru yang berbeda. Penilaian autentik mengharuskan pembelajaran yang autentik pula. Menurut Ormiston (1979), belajar autentik mencerminkan tugas dan pemecahan masalah yang diperlukan dalam kenyataannya di luar sekolah. Penilaian autentik terdiri dari berbagai teknik penilaian. Pertama, pengukuran langsung keterampilan peserta didik yang berhubungan dengan hasil jangka panjang pendidikan seperti kesuksesan di tempat kerja. Kedua, penilaian atas tugastugas yang memerlukan keterlibatan yang luas dan kinerja yang kompleks. Ketiga, 
analisis proses yang digunakan untuk menghasilkan respon peserta didik atas perolehan sikap, keterampilan, dan pengetahuan yang ada (Kemendikbud. 2013).

Sesuai dengan karakteristik IPA sebagai natural science, pendekatan pembelajaran yang sesuai adalah saintifik yang merefleksikan kompetensi sikap ilmiah, berfikir ilmiah, dan keterampilan kerja ilmiah (Joice,2009). Kegiatan pembelajaran yang dilakukan melalui model inkuiri yang melibatkan proses observasi, melakukan pengukuran, berhipotesis, interpretasi, membangun teori, merencanakan penyelidikan, bereksperimen dan refleksi (Hebrank , 2000). Selanjutnya penelitian Rustaman N.Y (2005), pemebelajaran berbasis inkuiri akan bermakna apabila diberlakukan sebagai kemampuan kerja ilmiah yang dikembangkan, diterapkan, dan diukur selama proses pembelajaran dan sebagai perolehan pembelajaran

\section{METODE PENELITIAN}

Penelitian ini menerapkan metode penelitian mix (Kualitatif dan kuantitatif secara serentak). Metode kuantitatif digunakan untuk mendeskripsikan secara evaluatif fenomena yang berupa kuantitas, sedangkan metode kualitatif digunakan untuk memaknai secara verbal temuan-temuan penelitian sesuai dengan kualitas data penelitian.

Sesuai dengan karakteristik dan tujuan penelitian, prosedur penelitian ini mengikuti tahapan berikut: Pada tahun pertama menggunakan pendekatan ekploratif, mempelajari dan menghimpun data secara comprehensive, baru dan aktual dari interaksi enam komponen proses pendidikan (kurikulum, tenaga pendidik, peserta didik, sarana dan prasarana, teknologi dan media pembelajaran, evaluasi).

1. Studi literatur Survey awal permasalahan proses pendidikan

2. Konfirmasi permasalahan melalui seminar/pertemuan dengan guru dan kepala sekolah

3. Mengumpulkan permasalahan proses pendidikan secara conprehensive, baru, aktual

4. Deskripsi hasil temuan untuk memperoleh indikator metode pengumpul data

5. Verifikasi hasil temuan bersama stakeholder

6. Kristalisasi hasil verifikasi

7. Cross chek berbagai informasi dari berbagai sumber 


\section{a. Populasi dan Sampel}

Pengambilan populasi di kota Padang dikarenakan $30 \%$ jumlah guru dan siswa Sumatera Barat berada di kota Padang. Sampel diambil $25 \%$ menggunakan teknik cluster random sampling. Setelah menetapkan sampel secara random sesuai dengan jenis, status dan lokasi sekolah, maka terpilih 10 sekolah. Dari unit analisis sekolah sebagai sampel supaya terpilah dengan baik, maka dipilih secara acak responden 1 orang guru dan 20 orang siswa untuk masing-masing sekolah.

\section{b. Teknik Pengumpulan Data}

Instrumen yang digunakan pada penelitian berupa angket, interview dan observasi. Sebelum penyusunan instrumen diawali dengan mengadakan seminar awal untuk mendapatkan informasi tentang permasalahan proses pelaksanaan Kurikulum 2013 secara conprehensive, baru, aktual. Seminar ini dipandang kritikal karena merekalah guru, kepala sekolah dan kepala dinas pelaku utama di lapangan. Melalui seminar diharapkan hambatan pelaksanaan Kurikulum dalam hal-hal yang menunjang akan dapat diidentifikasi. Setiap sekolah sampel diundang kepala sekolah dan wakil kepala sekolah bidang kurikulum dan guru bidang studi. Mereka diminta menjelaskan keunggulan dan apa hambatan dalam pelaksanaannya.

Untuk menghimpun data penelitian sesudah mendapatkan informasi kritikal dari studi kepustakaan dan informasi yang diperoleh melalui seminar, serta kunjungan ke sekolah sampel, disusun kisi-kisi instrumen sebagai pedoman penjaringan informasi melalui angket, interview dan observasi. Kisi-kisi yang disusun berdasarkan enam komponen proses pembelajaran (kurikulum, guru, siswa, sarana dan prasarana, media pendidikan/teknologi, dan evaluasi).

\section{c. Teknik Analisis Data}

Teknik analisis terdiri dari analisis kualitatif dan analisis kuantitatif. Analisis kualitatif dari dokumen Kurikulum 2013, hasil wawancara, hasil observasi yang telah terkumpul dipelajari untuk dideskripsikan, kemudian dianalisis sesuai dengan jenis dan karakteristik informasi yang diperoleh. Analisis kuantitatif dari hasil jawaban angket guru dan siswa diolah menggunakan statistik sederhana persentase dengan bantuan program SPSS, kemudian data diringkas dalam bentuk matriks untuk melakukan klasifikasi hasil-hasil penelitian. Selanjutnya, data dianalisis, dievaluasi, dan ditafsirkan secara objektif.. 


\section{HASIL DAN PEMBAHASAN}

\section{Hasil Kualitatif Pembahasan Permasalahan Sehubungan Kurikulum 2013.}

Implementasi Kurikulum 2013 bertumpu kepada bentuk dan kegiatan proses belajar di dalam ruang kelas tampaknya memberikan dampak yang tidak diharapkan. Banyak pentunjuk sosialisasi Kurikulum 2013 menekankan kepada proses pembelajaran di ruang kelas dan belum mempertimbangkan faktor-faktor dominan yang menyebabkan proses tersebut tidak optimal. Misalnya dalam salah satu petunjuk menekankan kepada mengubah strategi pembelajaran dengan menggunakan pendekatan saintifik, sehingga memungkinkan:

- Peserta didik lebih aktif

- Iklim belajar menyenangkan

- Pengembangan budaya baca, tulis, observasi

- Fungsi guru bergeser dari pemberi inoformasi menuju seorang fasilitator

- Pemanfaatan perpustakaan, laboratorium, dan sumber belajar lain,

- Materi yang dipelajari terkait dengan lingkungan kehidupan peserta didik, sehingga dapat dimanfaatkan untuk memecahkan masalah kehidupan.

- Peserta didik terbiasa mencari informasi dari berbagai sumber

- Menggeser "teaching" menjadi "learning"

- Penilaian berbasis kinerja peserta didik dan menekankan pada keterpaduan sikap, pengetahuan, dan ketrampilan menggunakan berbagai cara dan instrumen.

- Lebih banyak komponen-komponen dalam kecakapan hidup yang biasa diinternalisasikan dalam PBM.

Tidak ada yang salah dari pernyataan di atas, semuanya memberi tahu apa yang harus dikerjakan guru namun belum membahas mengapa itu perlu dan apa penyebab utama yang memungkinkan seluruh indikator tersebut dapat dikerjakan. Kita lebih banyak berbicara tentang apa yang harus dikerjakan tetapi lupa untuk apa itu dikerjakan dan faktor apa yang penting diperhatikan agar semua itu dapat dilakukan. Penelitian sekolah Efektif di luar negeri lebih banyak mencari penyebab mengapa proses pembelajaran dapat ditingkatkan (Scheerens, j., 2000; Brighouse, T. \& Woords, D., 1999). Penelitian Festiyed dan Syakbaniah (2011) menunjukkan bahwa asesmen berbasis kelas seperti: Asesmen porto folio (Portofolio assessment); Asesmen kinerja (Performance assessment); Asesmen penugasan (Project assessment); Asesmen tertulis (Paper \& Pencil assessment ); dan Asesmen hasil kerja (Product assessment) belum dilaksanakan sebagaimana mestinya. Proses asesmen yang dilakukan selama ini hanya menekankan pada penguasaan konsep. Asesmen hanya meliputi ranah kognitif belum sampai pada C6 (kreasi), kebanyakan bentuk asesmen tertulis berupa memilih jawaban atau mensuplai 
jawaban. Keadaan ini mendorong peserta didik untuk menghafal sewaktu akan diadakan tes harian atau tes hasil pembelajaran. Asesmen yang ada belum dapat mengungkap secara terpadu aspek kognitif, efektif dan psikomotor. Mungkin ini pulalah yang menyebabkan pengembangan Kurikulum di Indonesia lebih banyak pengembangan kepada bentuk dari pada kepada rohnya pengembangan sekolah yang lebih efektif.

\section{Hasil Kuantitatif dan Pembahasan Permasalahan Sehubungan Kurikulum 2013}

Tingkat pendidikan guru hampir seluruh sekolah telah memenuhi syarat minimal ijazah guru SLTA (Permendiknas no.41, 2007), sekitar 94\% telah memiliki ijazah S1, S2 dan S3. Hanya sekitar 6\% yang belum memenuhi syarat atau masih memiliki ijazah D3.

Penerapan Kuikulum 2013 berimplikasi pada bertambahnya beban bagi guru. Dari data beban mengajar guru 38\% guru yang memenuhi standar BSNP, 20\% melebihi beban dan $42 \%$ beban rendah. Diperoleh sekitar $55 \%$ guru mengajar di sekolah lainnya. Sedang distribusi guru yang mengajar di sekolah lain menurut lokasi rural dan urban relatif mendekati sama. Untuk guru yang bebannya berlebih sulit dibayangkan sekolah tersebut untuk berkembang. Hal ini berkaitan adanya pergeseran peran guru yang semula lebih sebagai instruktur dan kini menjadi fasilitator pembelajaran.

Kesesuaian matapelajaran yang diampu guru sekitar $74 \%$ sesuai dengan pendidikan terakhirnya dan masih terdapat $5 \%$ yang tidak sesuai dengan pendidikan terakhirnya. Ini menunjukkan peranan kepala sekolah dan dinas pendidikan dalam pengangkatan dan penempatan belum memperhitungkan kebutuhan guru dengan matapelajaran yang ada. Pemberdayaan guru belum dilakukan sepenuhnya oleh pemerintah daerah (pemda). Misalnya, pemda belum melakukan evaluasi pendidikan, termasuk evaluasi guru. Ini yang kerap terjadi, sehingga penerapan Kurikulum 2013 pun bisa melambat.

Implementasi Kurikulum 2013 sebenarnya membutuhkan penciptaan iklim pendidikan yang memungkinkan tumbuhnya semangat intelektual dan ilmiah bagi setiap guru, mulai dari rumah, di sekolah, maupun di masyarakat. Dalam mengembangkan semangat intelektual guru salah satunya dapat melalui keikut sertaan dalam seminar. Sehubungan dengan seminar yang berhubungan dengan penelitian guru sekitar $12 \%$ setiap tahunnya telah mengikuti dan $31 \%$ sama sekali belum mengikuti seminar. Selanjutnya seminar yang berhubungan dengan pembelajaran dan pendidikan terbaru $15 \%$ telah mengikuti dan $12 \%$ belum mengikuti.

Proses pembelajaran yang baik seharusnya membawa siswa ke alam nyata (CTL), Penelitian ini mengajukan pertanyaan seberapa persen guru yang membawa siswa praktikum ke labor dan ke ke lapangan. Temuan penelitian ini sekitar $19 \%$ guru telah 
membawa siswa ke labor sebanyak lebih dari 6 kali untuk satu semester, sedang $47 \%$ guru belum membawa siswa ke labor untuk praktikum. Sekitar $4 \%$ guru telah membawa siswa ke lapangan untuk praktikum sebanyak lebih dari 6 kali untuk satu semester, dan hanya $55 \%$ yang belum membawa siswa ke lapangan.

Kaitan ijazah guru dengan kegiatan seminar dan kegiatan membawa siswanya ke labor dan kerja lapangan dapat dilihat pada Gambar 1.

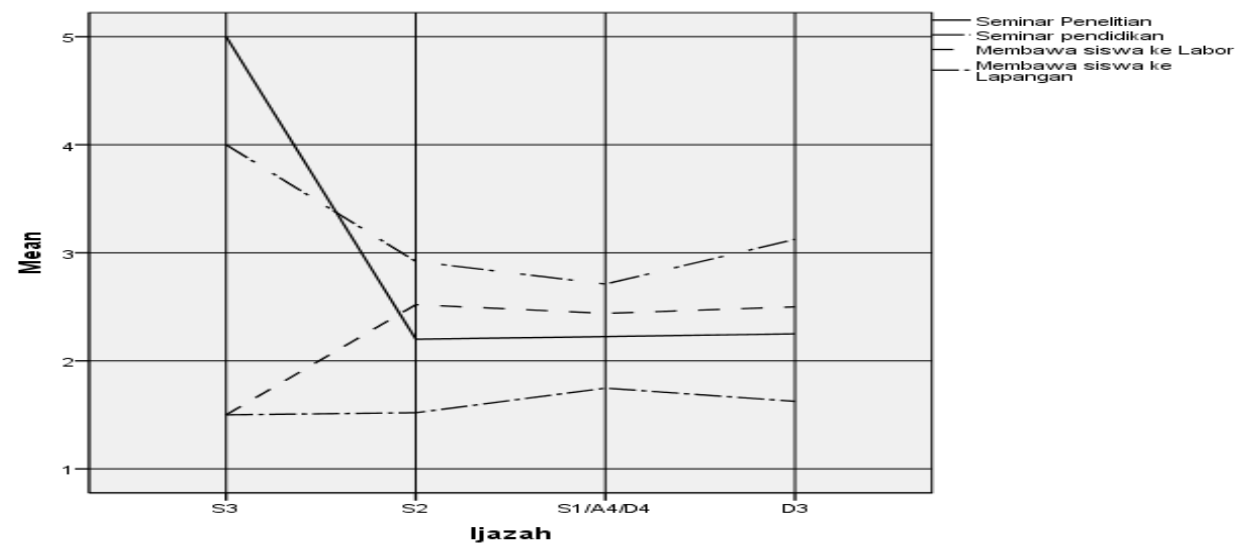

Gambar 1. Grafik ljazah guru dengan kegiatan seminar dan kegiatan labor (Festiyed, Syajbaniah 2011)

Dari temuan tersebut di atas dapat disimpulkan perhatian kadinas dan kepala sekolah memandang bahwa kebutuhan labor tidak kritikal dibandingkan dengan capaian hasil pembelajaran dan banyaknya siswa yang lulus. tambahan pula kurangnya inisiatif guru untuk memanfaatkan alam sebagai laboratorium terbuka dan belum berorientasi pada kualitas proses pembelajaran dan membelajarkan anak.

Dalam pembelajaran bentuk tugas yang diberikan oleh guru kebanyakan dalam bentuk respon tertulis, diskusi dan presentasi masing-masing $75 \%, 89 \%$ dan $68 \%$ baik untuk sekolah negeri maupun swasta yang berasal dari kelompok rural atau urban. Ini menunjukkan penguasaan tugas evaluasi pendidikan pengajaran masih belum memadai.

Perangkat pembelajaran telah digunakan guru berupa RP $96 \%$, LKS $70 \%$, Ringkasan materi $78 \%$, modul $57 \%$, buku ajar $73 \%$, buku paket $63 \%$, tetapi LDS hanya $24 \%$ Kalau dibandingkan dengan tugas yang digunakan, pada kegiatan diskusi $89 \%$ memerlukan LDS. Untuk buku guru dan buku siswa 47\%. Data ini memperkokoh kesimpulan bahwa pemahaman guru tentang tugas pengajaran masih sangat mekanistik.

Untuk mengoptimalkan pemberdayaan guru dalam mengimplementasikan kurikulum tersebut, harus didukung sejumlah sarana dan fasilitas seperti ketersediaan buku teks yang beragam, dan memerlukan banyak sumber seperti buku, dan internet. Guru dapat 
memusatkan perhatian pada pengembangan kompetensi peserta didik dengan menyediakan aneka ragam kegiatan belajar mengajar dan sumber belajar. Hasil penelitian penggunaan media pembelajaran sudah bervariasi, tetapi kalau dilihat hasil belajar siswa belum optimal, kebanyakan siswa memperoleh nilai di atas 75 hanya $12 \%$.. Hasil ini kontradiktif dengan teori Dale (1969), bahwa penggunaan media yang bervariasi akan meningkatkan capaian pembelajaran siswa. Mungkin guru terlalu banyak menggunakan media sehingga tidak memusatkan perhatian siswa. Ini memperlihatkan bahwa pemahaman guru tentang media masih sederhana.

Dari fakta tersebut di atas, walaupun ijazah guru sudah memenuhi syarat dan sebaran guru antara urban dan rural sudah relatif proposional, namun penelitian ini membuktikan bahwa penguasaan evaluasi dan metoda mengajar belum memadai. Hal ini mungkin disebabkan guru sudah sangat percaya diri sehingga merasa tidak perlu lagi mengembangkan potensi diri. Pada hal bila dilihat dari persepsi siswa hal tersebut bertolak belakang, seperti dapat dilihat pada Gambar 2 .

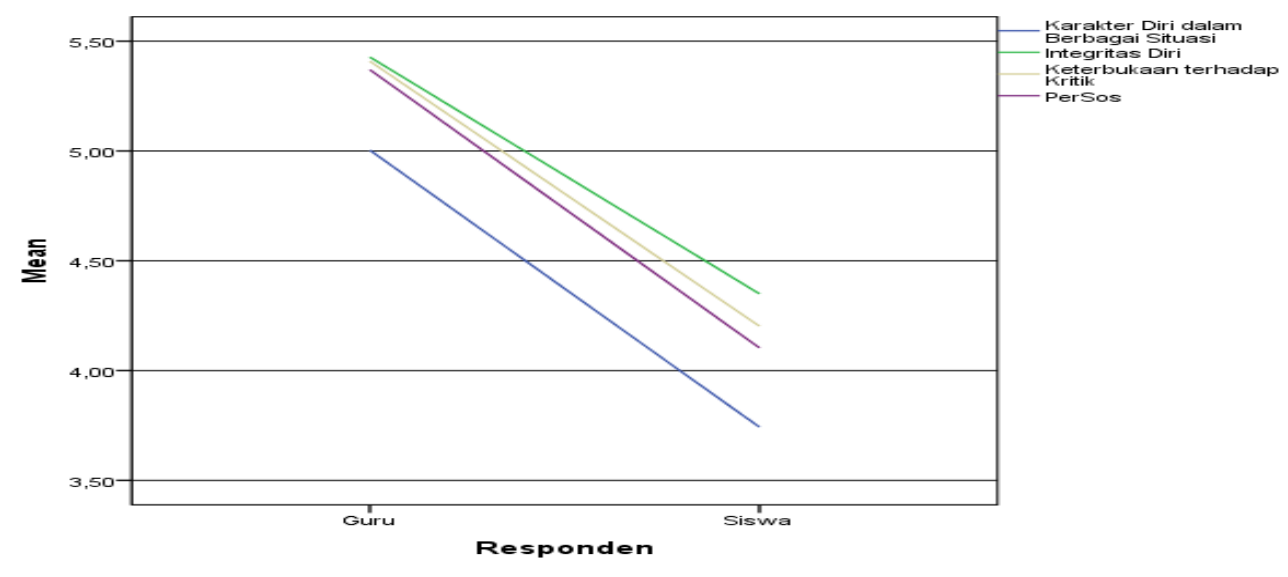

Gambar 2. Persepsi guru dan persepsi siswa tentang gurunya

(Festiyed, Syajbaniah 2011)

Gambar 2 memperlihatkan karakter diri, integritas diri, keterbukaan terhadap kritik, peran sosial guru dilihat dari persepsi guru dan persepsi siswa. Dari grafik terlihat bahwa untuk semua komponen guru cendrung menilai dirinya terlalu tinggi, sementara siswa menilai sebaliknya.

Faktor situasi lingkungan belajar yang juga berperan dalam pembelajaran seperti pencahayaan dan kebisingan lingkungan sekolah. Jika dibandingkan dengan standar di negara kita tentang penerangan buatan untuk kelas yaitu 200 - 300 lux. (Standar Penerangan Buatan dalam Gedung,1978), dan untuk kebisingan pada zona B (Intensitas 45-55 dB, Zona yang diperuntukkan bagi perumahan, tempat Pendidikan dan rekreasi). Maka intensitas cahaya dalam kelas dan perpustakaan sudah memenuhi standar, tetapi 
labor belum memenuhi. Untuk intensitas bunyi pada semua ruangan berada diatas $55 \mathrm{~dB}$, jadi diatas standar kebisingan. Mungkin ini pulalah sulitnya siswa berkonsentrasi belajar yang akhirnya juga akan menurunkan prestasi belajarnya.

Bila dilihat dari: pelaksanaan Kurikulum 2013, lingkungan sekolah, suasana ruang kelas, pengetahuan tentang ilmu pendidikan, usaha dan dampak perubahan kurikulum, produktivitas pengembangan keilmuan, karakter guru dalam berbagai situasi, integritas diri, keterbukaan terhadap kritik, peran sosial, idealisasi pimpinan, kebutuhan stakeholders, lingkungan sekolah, karakteristik siswa, ternyata empat indikator yang mediannya berada dibawah rata-rata adalah: lingkungan sekolah, pengetahuan tentang ilmu pendidikan, usaha dan dampak perubahan kurikulum, suasana ruang kelas. Chart ini mempertegas temuan sebelumnya. Untuk terlaksananya Kurikulum 2013 diperlukan lingkungan sekolah dan suasana ruang kelas yang mendukung, guru yang dapat memainkan perannya sebagai motivator, dinamisator, fasilitator, inisiator, kreator, ilustrator, konduktor, administrator koordinator dan manajer, evaluator, promotor, desainer, dan eksekutor.

Selanjutnya dilihat indikator: penguasaan materi, menguasai ilmu pendidikan, menguasai cara membimbing siswa, menguasai metode pembelajaran melaksanakan evaluasi, perencanaan pembelajaran, integritas kepribadian, kompetensi sosial, etos kerja, kekhasan sekolah. Terdapat enam indikator yang mediannya berada dibawah ratarata adalah: penguasaan materi, menguasai ilmu pendidikan, menguasai cara membimbing siswa, menguasai metode pembelajaran, melaksanakan evaluasi, perencanaan pembelajaran. Kalau dilihat pendapat Tyler (perencanaan tujuan, pengalaman, metoda dan evaluasi pembelajaran) berarti seluruh aspek kurikulum Behavioristik belum terpenuhi

\section{KESIMPULAN DAN SARAN}

\section{Kesimpulan}

Hasil penilaian proses pembelajaran belum optimum dalam meningkatkan pembelajaran bidang studinya, juga penilaian yang dilakukan masih belum memadai, pemahaman guru tentang tugas pengajaran masih sangat mekanistik.

Dari pelaksanaan Kurikulum 2013, lingkungan sekolah, suasana ruang kelas, pengetahuan tentang ilmu pendidikan, usaha dan dampak perubahan kurikulum, produktivitas pengembangan keilmuan, karakter guru dalam berbagai situasi, integritas diri, keterbukaan terhadap kritik, peran sosial, idealisasi pimpinan, kebutuhan stakeholders, lingkungan sekolah, karakteristik siswa, ternyata empat indikator yang 
mediannya berada dibawah rata-rata, yaitu: lingkungan sekolah, pengetahuan tentang ilmu pendidikan, usaha dan dampak perubahan kurikulum dan suasana ruang kelas.

Indikator: penguasaan materi, menguasai ilmu pendidikan, menguasai cara membimbing siswa, menguasai metode pembelajaran melaksanakan evaluasi, perencanaan pembelajaran, mediannya berada dibawah rata-rata, berarti seluruh aspek Kurikulum 2013 belum terpenuhi. Dan ketersediaan sarana dan prasarana pendidikan masih belum memadai.

\section{Saran}

1. Perlu Pengebangan Kurikulum secara integratif, dan sistematik sehingga ditemukan cara-cara yang efektif untuk mencapai tujuan pendidikan dan tinggalkan pendekatan "component wise" dalam pengembangan.

2. Menggunakan teknologi untuk merekam data Penerapan Kurikulum 2013 dan biasakan menggunakan data dalam merumuskan kebijakan.

3. Diperlukan penelitian yang lebih komprehensif untuk mendukung kebijakan penerapan Kurikulum 2013 di Indonesia.

\section{PUSTAKA ACUAN}

Kementrian Pendidikan dan Kebudayaan. 2013. Kurikulum 2013. Medan. Unimed Press.

--------Permendikbud Nomor 103 Tahun 2014, tentang Pembelajaran pada Pendidikan dasar dan Pendidikan Menengah.

-------- Permendikbud Nomor 104 Tahun 2014, tentang Penilaian Hasil Belajar oleh Pendidik pada Pendidikan dasar dan Pendidikan Menengah.

------ Permendikbud Nomor 160 Tahun 2014, tentang Pemberlakuan Kurikulum 2006 dan 2013

Aljufri B. S. 1998. Analisis Kebutuhan Pengembangan Kurikulum FPTK-IKIP Padang dalam menghadapi era Persaingan Global. Disampaikan pada Seminar Lokakarya

Brighouse, T. \& Woods, D. (1999). How to Improve Your School. London: Routledge.

Dale, E.(1969) . Audio Visual Methods in Teaching.(Third Edition). New York: The Dryden Press, Holt, Rinehart and Winston, Inc.

Festiyed, Syakbaniah (2011). Permasalahan Dalam Mengimplementasikan Kurikulum Tingkat Satuan Pendikan Sekolah Menengah Di Kotamadya Padang Sumatera Barat (2008-2009). Makalah dipresentasikan dalam Seminar Nasional Lesson Study ke-4. Universitas Negeri Malang. Malang (Prosiding)

Goldstein, H. \& Thomas, S. (1995). School effectiveness and value added analysis. Forum, 37, 2, 36-8. 
Hebrank, M. (2000). Why Inquiry-Based Teaching and Learnng in the Midle School Science Clssroom?. [online] http://www.zoology.duke.edu/cibl (diakses 16 Februari 2014).

Joyce, Bruce. Weil, Massha. \& Calhoun, Emily. 2009. Models of Teaching. United Stated of America: Person Education, Inc.

Ouston, J. ,Rutter, M., Maughan, b., Dan Mortimore, P. (1979). Fifteen Thousand Hours: Secondary Schools and teir Effects on Children. London: Open Books.

Rustaman. N.,Y (2005). Perkembangan Penelitian Pembelajaran Berbasis Inkuiri Dalam Pendidikan SAINS. Makalah dipresentasikan dalam Seminar Nasional II Himpunana ikatan Sarjana dan Pemerhati Pendidikan IPA Indonesia Bekerjasama dengan FMIPA UPI Bandung 22-23 Juli 2005.

Scheerens, J. (2000). Improving School Effectiveness. Paris: Unesco: International Institute for Educational Planning. 